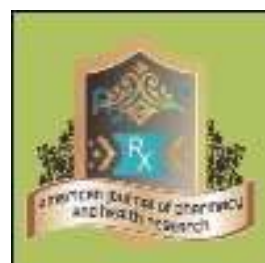

Review Article AMERICAN JOURNAL OF PHARMACY AND HEALTH RESEARCH www.ajphr.com

2019, Volume 7, Issue 11

ISSN: 2321-3647(online)

\title{
Acne Treatment by Nanomedicine Approach
}

\author{
Monika Targhotra,_Neha Raina, Madhu Gupta* \\ Department Of Pharmaceutics, Delhi Pharmaceutical Sciences and Research University, \\ PushpVihar Sec- 3, New Delhi
}

\begin{abstract}
Acne is one of the most common disorders that dermatologists and other health care providers treat. Although it most often affects adolescents, it is not uncommon in adults and can also be seen in children.Acne is a tenacious incendiary human skin syndrome, mainly defined at particular areas of skin characterized by microcomedones, comedones, nodules, pustules, itchiness, as well as invasive scar mainly on different parts of the body. Acne is a chronic inflammatory disorder of pilosebaceous unit that occurs for chronic periodas a result of increased sebum production induced by androgen, altered keratinisation, inflammation, and bacterial colonisation of hair follicles on the face, neck, chest, and back by Propionibacterium acnes. Different nano-advancement techniques like vesicular, colloidal drug delivery system have been discussed. These systems can be useful in scheming a novel delivery with low dose treatment for the cure of acne vulgaris. The current review focused on the better nanotechnological system that can be used in future for better and effective treatment of acne.
\end{abstract}

Keywords: Nanomedicine, Acne, Drug Delivery, Topical Delivery etc. 


\section{INTRODUCTION}

Skin break out vulgaris is an endless incendiary malady of the pilosebaceous unit (involving the hair follicle, hair shaft and sebaceous organ) and is among the most widely recognized dermatological conditions around the world, with an expected 650 million individuals influenced. Skin break out is viewed as a perpetual infection inferable from its drawn out course, example of repeat and backslide, and indications, for example, intense flare-ups or moderate beginning. In addition, skin break out causes significant negative mental and social impacts on the personal satisfaction of patients. $85-95 \%$ of teenage boys \& girls are affected. Very nearly $20 \%$ of these youngsters have moderate-to-extreme skin break out and upwards of half keep on experiencing skin break out in adulthood[1-4]. It is a condition defined as a persistent seditious syndrome of skin in the glandulaesebaceae. It is basically a polymorphism disarray with complex focalization. It is a skin condition occurring in the sebaceous glands and hair follicles and shown in Fig 1.[5]It occurs as An extensive period situation of the skin identified through the open comedones, greasy skin, inflammation and whiteheads, and invasive scar. The emergence may be capable of result toward apprehension, low confidence, also in severe conditions despair.[6] It results from relations between various factors. Androgens, particularly dehydroepiandrosterone sulfate (DHEAS), formed in the adrenal cortex, activate the sebaceous glands. The sebaceous glands are responsible for synthesizing more effective androgens from DHEAS, as they possess weakly androgenic activity. Firstlymicrocomedones are formed in the pilosebaceous unit due to retention and hyperkeratosis and then they become larger easily visible to the naked eye. Feasible factors in this are as follows: Altered sebum composition ,Bacterial metabolic products(lipase, protease, hyaluronidase), Inflammatory mediators (il-1 $\alpha$ )Androgens Propionibacterium acnes (P.acne) is an anaerobic organism present in acne lesions. $\mathrm{P}$ acnes are mainly responsible for inflammation through a range of mechanisms. Proinflammatory mediators are produced that mainly diffuses through the follicle wall due to the stimulation of inflammation by $\mathrm{P}$. acne bacteria. Itstimulates the toll-like receptor 2 on monocytes and neutrophils. Multiple inflammatory tumor necrosis factor, lymphokine tumour mortification factors are produced due to the stimulus the protein cluster of differentiation [7]. The classification of acne according to the severity includes Gentle skin inflammation- Less than 20 comedones or less than 15 fiery injuries, or aggregate injury tally less than 30.Secondly Moderate skin break out 20- 100 comedones, or 15- 50 incendiary injuries, or aggregate sore check 30- 125 and lastly extreme skin break out in excess of 5 knobs, or Aggregate incendiary check more prominent than 50, or 
Aggregate sore tally more prominent than 125[8]. Some physiological and environment factors that influence acne are Menstrual cycle - skin inflammation have a tendency to compound the condition fourteen days before their menstrual cycle. It occurs mainly because of changes in the hormone level during the menstrual cycle. Anxiety and stress - mental stress affects hormonal levels inside the body. For example cortisol and adrenaline, that results in skin inflammation worsen condition. Climatic changes - climate changes into hot or severe humidity leads to excessive sweating which leads to acne easily. Oil based cosmetics -excessive amount of oil present in moisturizing creams, lotions mainly leads to blocking of pores on the skin. Greasy hair -most of the hair products are greasy in nature and they also leads to blocking of pores. Hair items with cocoa spread or coconut margarine are precedents. Pressing the pimples- it leads to skin inflammation that will probably deteriorate, in addition to scarring also occurs [9] DietReports are accessible to build up the connection between dietary control and the skin break out related with biochemical and endocrine parameters. Admission of drain amid youth is for the most part connected with history of young skin break out. Immediate breakfast drink, cream cheddar and curds are additionally answered to be related with skin break out.

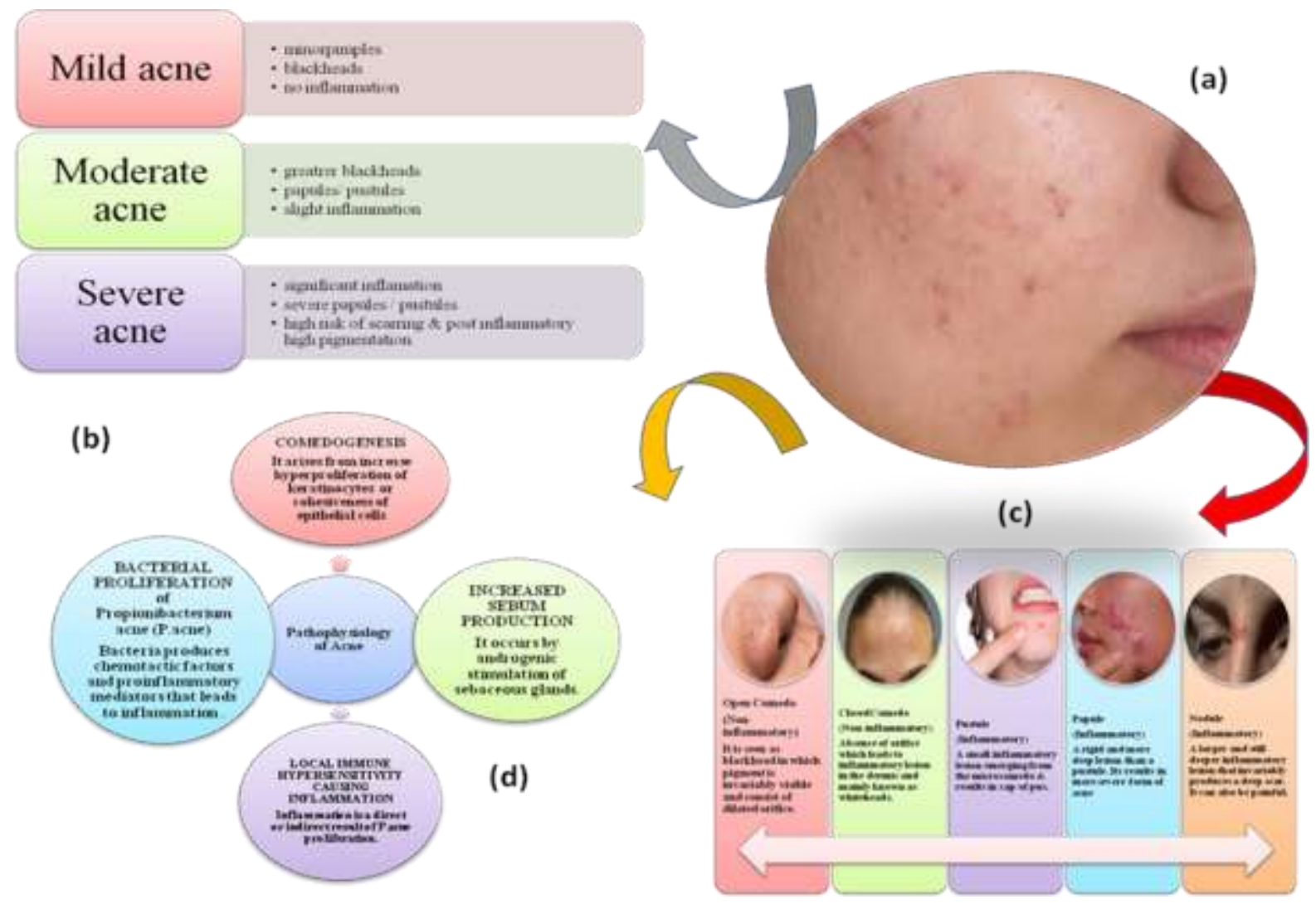

Figure 1: Schematic representation of (a)Acne, (b) causes and (c) types of acne according to severity and (d) pathophysiology of acne lesions 


\section{PATHOPHYISOLOGY OF ACNE}

Skin acne is a perplexing disorder happening with multifactorial pathogenesis and broad contrast in seriousness. Along these lines, treatment can be proposed for a few factors and adjusted for individual patients. It is an ailment of the sebaceous follicles, which are specific pilosebaceous units arranged on the face, neck, chest, upper back, and upper arms. These pilosebaceous units comprise of modestly vast sebaceous organs aligned with little hair follicles. It for the most part emerges from the collaboration of 4 factors.[6,7] There are 2 major sorts of skin break out injuries: Non inflammatory and Incendiary. Non inflammatory injuries of skin break out are the open (clogged pores) or shut (white heads) comedones. Incendiary injuries are characterized relying upon the seriousness and area inside the dermis as papules, pustules, and knobs/nodulocystic sores. Androgen stimulation leads to microcomedone formation and later on inflammatory lesions (papules and pustules). The papules and pustules have close-by radiances of erythema coming about their portrayal as provocative. Knobs are regularly erythematous and frequently painful. Moreover, they are profound established in the skin (i.e, focused in the dermis or subcutis).Nodules have been characterized as being more prominent than $5 \mathrm{~mm}$ in width and shown below Fig 1. [6,8].

\section{Treatment of Acne}

Treatment options differ with the stage and strength of the disease. As per the seriousness, skin inflammation can be distinguished as gentle, moderate, or extreme. The primary goals of acne management are to improve clinical symptoms, prevent scarring and reduce psychological stress. The determination of skin inflammation treatment ought to rely upon an expansive thought of the illness, together with a record of past treatments and reaction to these medications, and in addition a watchful physical examination. Topical treatment is the principal alternative in gentle and moderate skin break out, while fundamental treatment is utilized to treat extreme and moderate cases. Acne is mainly treated in three different ways and shown in Fig 2. [8] 


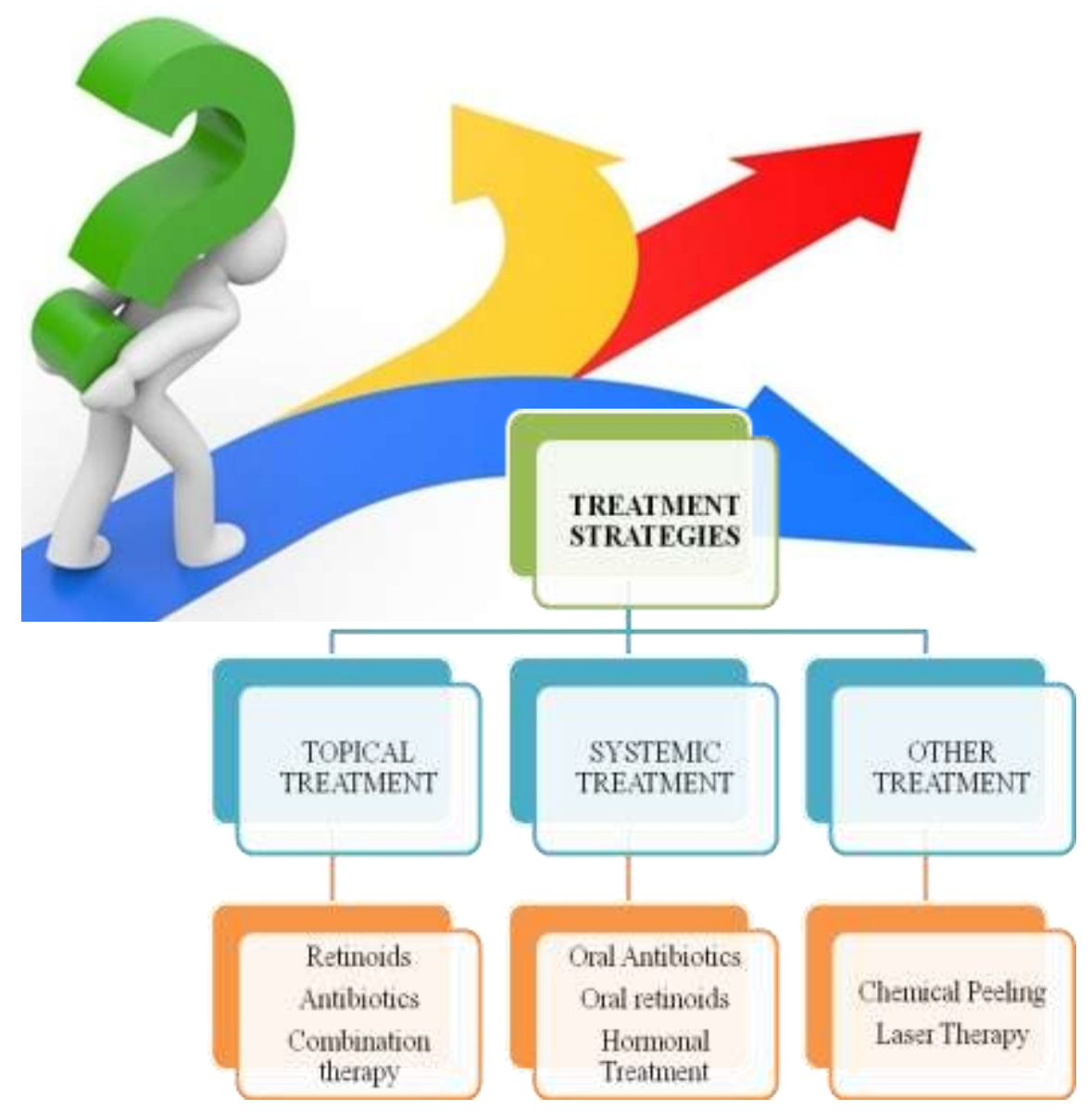

Figure 2: Treatment Strategies for Acne Vulgaris.

\section{Topical Treatment}

It is the primary decision in skin inflammation treatment: as monotherapy in mellow types of skin inflammation, or in mix with fundamental specialists in moderate and serious cases. It includes the use of antibiotics, retinoid and combination medication. Topical prescriptions are dynamic just where and when they are connected, while their fundamental activity is anticipation of new injuries. [10]

\section{Systemic Treatment}

Oral anti-infection agents are utilized for the treatment of moderate and extreme skin break out, skin break out that is impervious to topical treatment and skin inflammation that spreads huge parts of the body surface. It includes the use of antibiotics, retinoids, and combination medication. P. acnes is very delicate in vitro to various antimicrobial specialists of various classes, including macrolides, antibiotic medications, penicillins, clindamycin, minocycline, doxcycline, trimethoprim, and sulfonamides. The viability of these specialists, when offered 
foundationally to treat skin inflammation, relies upon their capacity to achieve the lipid-rich condition of the pilosebaceuos follicles where P. acnes multiply.

\section{Hormonal Treatment}

Combination oral contraceptive pills (COCs) have been used for birth control since 1960 by impeding the release of hormones in females like luteinizing hormone, follicle stimulating hormone and gonadotropin-releasing hormone. Now a days, COCs also plays an important role in the treatment of acne. At present, ethinyl estradiol/norethindrone acetate/ferrous fumarate, ethinyl estradiol/drospirenone/levomefolate, ethinyl estradiol/drospirenone and ethinyl estradiol/norgestimate are the only four COCs available for the treatment therapy of acne which gained approval by Food \& Drug Administration. The action mechanism of these COCs is against the androgenic properties for the acne treatment therapy. These hormonal pills lessen the formation of androgen hormones in ovary and simultaneously upsurge the non-binding hormone testosterone in free circulating form, sex hormone binding globulin and causes its unavailability at the binding site of androgen receptors. Furthermore, COCs also cause reduction in the activity of 5-alfa-reductase and blocking of the receptors of androgen hormones. From the several clinical trial studies of acne, it was proofed that inflammation and counts of comedonal lesions are the two factors whose reduction comprises of the anti-acne activity of COCs [11].

\section{Other Treatments}

\section{Chemical peeling:}

Shallow concoction peeling has broadly utilized in the treatment of skin inflammation. Shallow peels are utilized to treat the epidermis. These are performed with the help of Alpha-Hydroxy Acids (AHA), and furthermore Beta-Hydroxy Acids (BHA). Alpha-hydroxy acids are characteristic acids comprise of glycolic corrosive, lactic corrosive, and, though beta-hydroxy acids include salicylic acid. The concentration of acid varies from treatment to treatment and they are no harsh in nature. Low convergences of AHA are for the most part blended with facial creams that can be utilized as every day facial consideration. Initial treatment with glycolic acid leads to some of the adverse effects. [12]

\section{Laser therapy:}

There are mainly two mechanisms involved for the treatment of acne. Firstly, through photodynamic reaction these used to destroy the $\mathrm{P}$. acnes and then, by obliterating the whole pilosebaceous unit. Photodynamic therapy is done with aminolevulinic corrosive by photograph initiation of the compound for the treatment of the skin. Sometimes photodynamic treatment leads to painful pustular reaction. Red and blue light treatment is fundamentally used to treat skin 
break out, and with the most current development convenient gadgets that entrance the patients to utilize light treatment at home. [12]

\section{NEED FOR NEW TREATMENT THERAPY}

Novel medication conveyance frameworks assume a vital job in refinement of anti-acne drug through topical delivery. They act mainly by increasing their dermal limitation with a related reduction in their unfavorable impacts. Focusing on is the capacity to guide the medication stacked framework to the site of interest. Controlled medication discharge and consequent biodegradation are noteworthy for creating fruitful details. The technique by which a medication is conveyed can significantly affect its adequacy and shown in Figure 3.

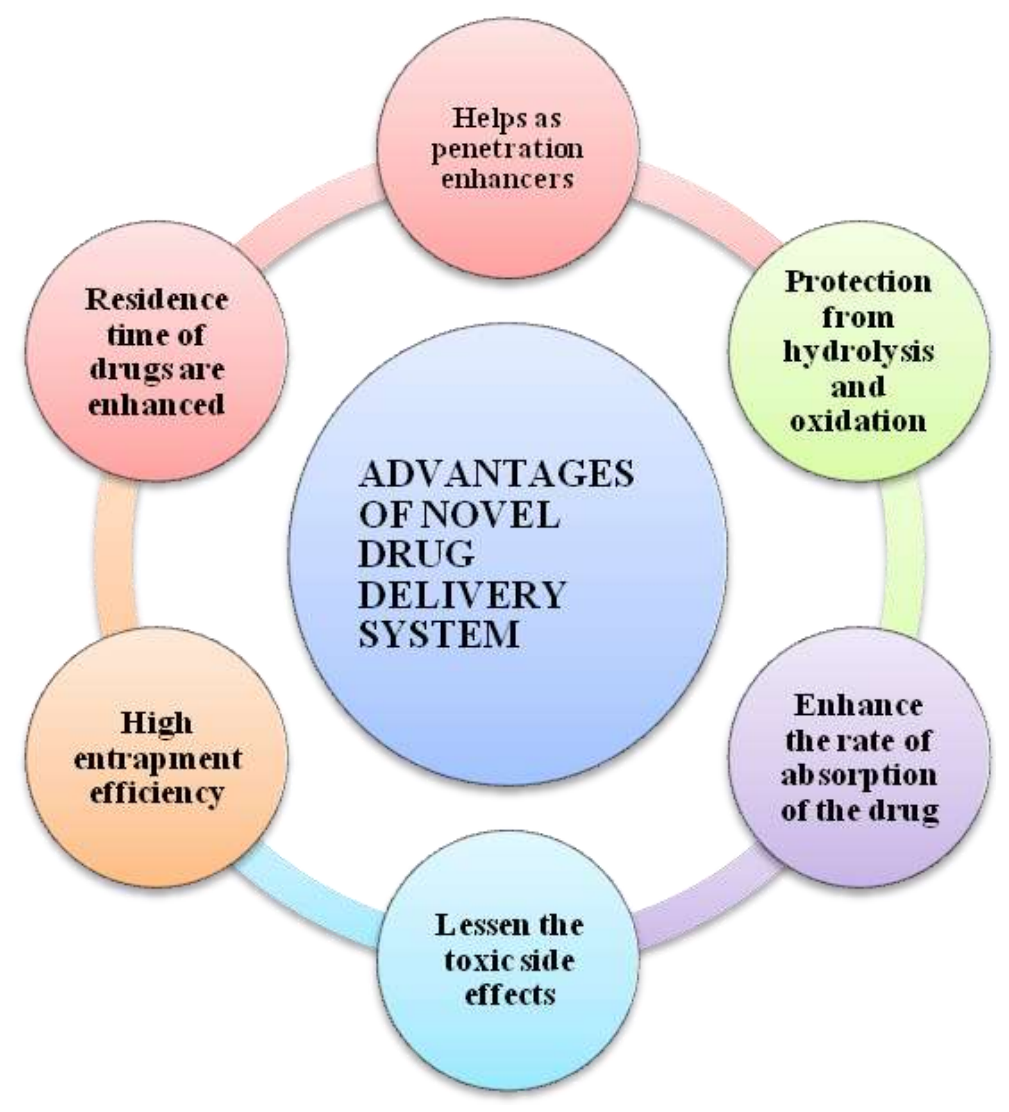

Figure 3: Benefits associated with Novel nanotechnology based nanocarrier system

Novel carriers are fast recognition, which incorporate utilization of a few transporters, for example, liposome, niosomes, transferosomes, emulsomes, nano emulsion, microemulsion, and nano lipid transporters that are gainful for the conveyance of medication through the skin. The main advantages of nanocarriers is enlisted in Fig. 3 and their representation in fig 4: [13] 


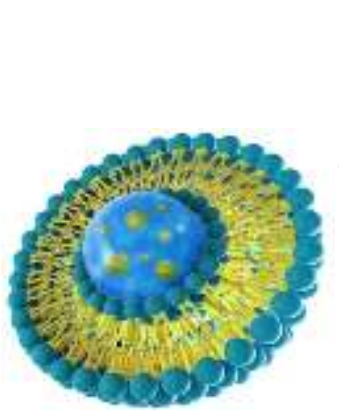

Liposome
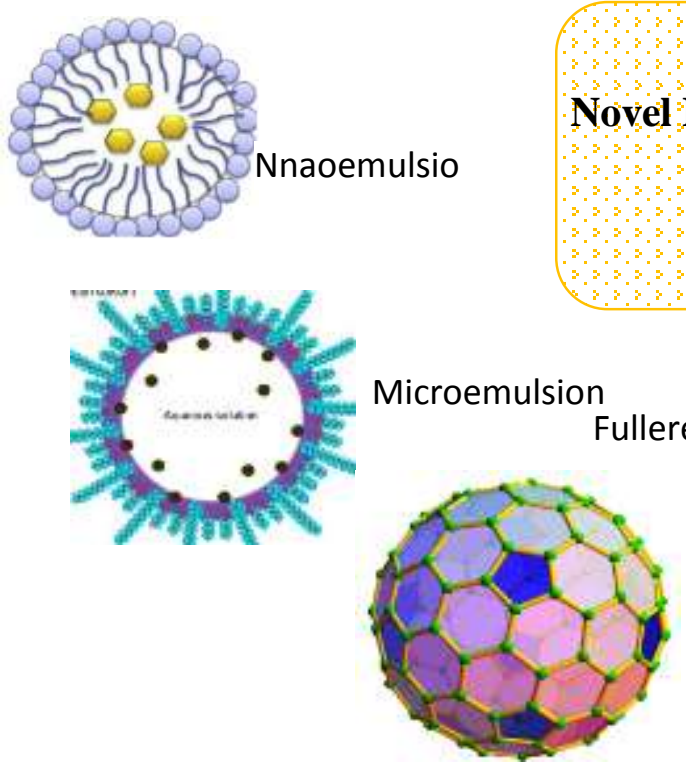
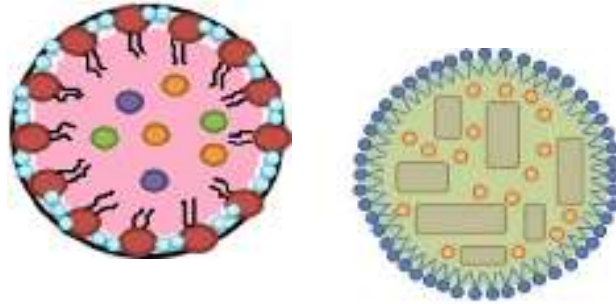

lipid Nanostructured

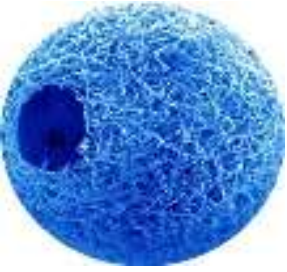

Microspheres

Nanoparticles

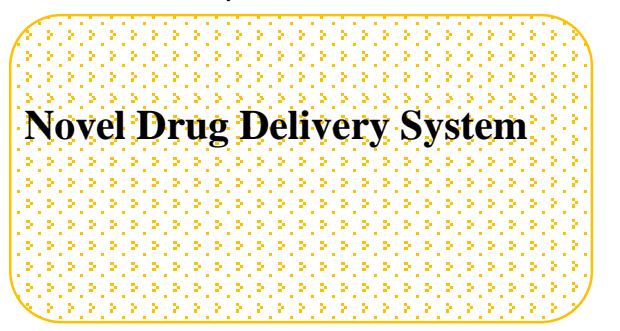

Hydrogels

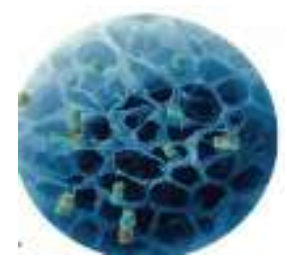

Microspong

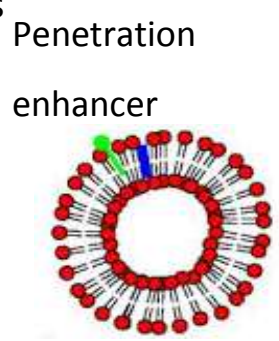

Aerosol

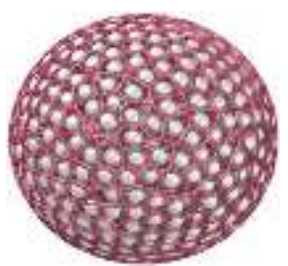

Figure 4: Various novel nanocarrier system

\section{Liposomes:}

The vesicular transporter for the conveyance of different medications to the specific areas or sites in the skin is an important delivery system. They result in formation of liposomes by coming in contact with water and getting hydrated. These are microscopic vesicles consist of phospholipid layer, ranging from twenty nanometer to one micrometer. For stabilization of membrane and enhancing the rigidity of vesicles, cholesterol is used in many formulations. It is capable of encapsulating both hydrophilic and lipophilic drugs. It involves delivery of triamcinolone acetonide in topical drug delivery system. liposomal formulation resulted significantly increase in the concentration of steroid in the epidermis and dermis. It was also shown in a study that triamcinolone acetonide loaded liposomes resulted in $\sim 5$-fold increase in drug accumulation in the epidermis as compared to gel formulation. Liposomal formulation has shown the higher concentration of drug betamethasone dipropionate as compared to commercial formulation. The liposomal formulation used in the treatment psoriasis Econazole resulted with 7 fold increase in the epidermis as compared to cream. [9] adapalene loaded liposomes was prepared for topical 
delivery by a simple and significant method. It liposomal was evaluated for different physicochemical parameters. They were found to be spherical in shape with below100 nm in size. DSC was performed which confirmed the merging of adapalene in the lipid bilayers. Preparation was stored for 3 months at refrigerated conditions, liposomes remained stable. In vitro permeation studies in which showed that liposomal formulation can notably enhance the permeation of adapalene into the hair follicles in pig ear skin as compared to drug solution and gel formulation. [14]

\section{Niosomes:}

Niosomes are unilamellar or multilamellar vesicles made up of non ionic surfactant where aqueous phase is encapsulated in bilayer. They are nonionic surfactant vesicles by which skin diffusion and accumulation are increased in the exterior skin stratum. Niosomes increases the residence time of drugs and systemic absorption is also reduced when it is applied topically. Niosomes are favored over liposomes because they show high chemical stability.[8] The niosomal preparation has been explored for delivery of tretinoin. The utility of niosomes for exemplifying tretinoin with the end goal to enhance its photochemical soundness. They arranged multilamellar, vast unilamellar and little unilamellarniosomes by utilizing polyoxyethylene (4) lauryl ether (Brij @ 30), sorbitan esters and a business blend of octyl/decyl polyglucosides (Triton ${ }^{\circledR}$ CG110) within the sight of cholesterol and dicetyl phosphate. [15]

\section{Solid Lipid Nanoparticle (SLN):}

Strong lipid nanoparticle (SLN) have demonstrated fascinating potential as a medication conveyance framework for the topical conveyance of different drug. It provide protection to the surface with the help of surfactant and hence stabilizes the dispersion. It provides some of the advantages like by giving protection to labile compounds against chemical degradation. It also produces controlled release forms of the active ingredients. To date, few studies with SLNloaded antiacne drugs have been conducted[16]. Isotretinoin-encapsulated SLN (IT-SLN) formulation SLN (IT-SLN) plan was set up for skin focusing for topical conveyance of isotretinoin. The SLN plans estimate was observed to be in the range somewhere in the range of 30 and $50 \mathrm{~nm}$. Plans appeared high ensnarement effectiveness going from $80 \%$ to $100 \%$. The in vitro pervasion information demonstrated that all the IT-SLN details can stay away from the fundamental take-up of isotretinoin in skins; anyway the control tincture had a penetration rate of $0.76 \pm 0.30 \_\mathrm{g} \mathrm{cm}-2 \mathrm{~h}-1$ through skins. The IT-SLN comprising of 3.0\% PRECIROL ATO 5, $4.0 \%$ soybean lecithin and $4.5 \%$ Tween 80 could altogether expanded the collective take-up of isotretinoin in skin and demonstrated a fundamentally improved skin focusing on impact. The 
examined IT-SLN demonstrated a decent security. These outcomes show that the examined ITSLN definition with skin focusing on might be a promising transporter for topical conveyance of isotretinoin. [17]

\section{Microspheres:}

Microsphere technology results in improvement of treatment acceptability, promote adherence, and leads to a enhanced long-term therapeutic results. Microsphere promotes controlled release delivery of drugs as it fastens the removal of high concentration of drug from the active site. It is related with enhanced treatment results and lessens the irritation. Tretinoin and benzoyl peroxide (BPO) marketed formulation for topical delivery of microsphere resulted in great viability and mediocrity and are unsurprising to advance adherence and long haul helpful assistance. [18] Tretinoin (TRT) mainly utilized in the treatment of comedonal and papulopustular Skin break out vulgaris for topical conveyance. It has a number of drawbacks which strongly bound its utility. To prevail over the disadvantages associated with tretinoin for the topical delivery, microsphere based sustained delivery were formulated using different techniques \& compared. It shows more than $80 \%$ of entrapment efficiency of all the formulations. The molecule measure was appeared to be in thin range. All the tretinoin loaded microsphere formulations shows sustain drug delivery for 12 hours.[19]

\section{NanoLipid Structured Carrier (NLC):}

Nanostructured lipid carriers consisting of strong framework at room temperature and mainly used as second generation drug carrier systems. It consists of mainly physical, eco-friendly, and biocompatible lipid resources and surface active agents are used for the purpose in various medication conveyance frameworks. They are preferred more as compared to different colloidal bearers like microemulsions, nanoparticles, liposomes, SLN, and so forth Advantages of NLCs. The distinctive position of advantages of NLCs consist of increased loading capacity of drug , prevention of drug exclusion, and drug release with better flexibility [4]. For example, Adapalene loaded nanostructured lipid carriers was prepared in combination with Vitamin $\mathrm{C}$ for the topical delivery. They resulted in accumulation in the hair follicles and increase the follicular delivery of the retinoid. Formulation were prepared to obtain the higher amount of drug into the carrier and it shows greater potential of skin targeting than free drug, and effect of antioxidant helped to enhanced the potential of drug during chronic therapy.[20]

\section{Hydrogel:}

Hydrogels occurs as colloidal gel in which water acting as a dispersion medium made up of network of polymer chains that are insoluble in water. Hydrogels are mainly occurring as natural 
or synthetic polymers which are superabsorbent in nature. Hydrogels hold greater amount of water or fluids inside it as it is three dimensional in structure. Due to its exceptional feature, hydrogels show excellent biomedical applications. [8] A Hydrogel patch was prepared containing triclosan in variable concentrations $(0.01-0.05 \% \mathrm{w} / \mathrm{v})$ and was characterized against P. acne for antimicrobial activity and in vitro permeation. As the concentration of drug increased, it resulted in the antimicrobial activity was achieved maximum. There was considerable raise in the quantity of triclosan delivered into the skincarried out during in vitro permeation studies.[14]

\section{Nanoemulsion:}

Nanoemulsion belongs to category of emulsions which can be w/o or o/w of formulations. The formation of nanoemulsion requires special thermodynamic conditions, specialized manufacturing processes and surfactant used for the stabilization of nanodroplets. They can easily incorporate the lipophilic structured compounds and hence used for the treatment of acne as these lipophilic compounds with nanoemulsion can easily penetrate into the pilosebaceous unit of the skin. Nanoemulsion produces therapeutic effect such as enhanced skin hydration and does not lead to clogging of the pores. [8]

\section{Microemulsion:}

These are semi-transparent blends of oil, surfactant, co-surfactant, and water, in which either the oil globules are scattered in water $(\mathrm{o} / \mathrm{w})$ or water globule are scattered in oils (w/o). Droplet size of microemulsion is $100 \mathrm{~nm}$ in diameter. To decrease the Surface tension between oil and water phase surfactants, cosurfactants are used. Co-surfactant plays role as penetration and exclusivity enhancer that results in improvement in skin penetration. [4]. First molecule used in the form of microemulsion was Azealic acid used in the treatment of acne. Water in oil microemulsion (using isopropyl myristate as an oily phase) used in the treatment of acne for the delivery of metronidazole. [14] Tretinoin lecithinsed microemulsion were prepared and evaluated. Characterization was done using TEM. The in vitro profile of novel microemulsion shows increase penetration into the skin with higher flux $(33.92 \mu \mathrm{g} / \mathrm{cm} 2 / \mathrm{hr})$ and gel $(31.54$ $\mu \mathrm{g} / \mathrm{cm} 2 / \mathrm{hr})$ in contrast with the plain medication arrangement $(22.33 \mu \mathrm{g} / \mathrm{cm} 2 / \mathrm{hr})$, plain medication in gel $(28.67 \mu \mathrm{g} / \mathrm{cm} 2 / \mathrm{hr})$ and the advertised readiness $(24.28 \mu \mathrm{g} / \mathrm{cm} 2 / \mathrm{hr})$. These results propose that the examined microemulsions might be proper vehicles for topical conveyance of tretinoin.[21]

\section{Emulsifier free formulation:}


Emulsifier free formulation without emulsifier plans are additionally a developing zone of improvement for dermatologic and restorative items. These are mainly occurring as Emulsions i.e, a blend of at least two fixings that are immiscible in nature. Therefore, for the stabilization of the formulation and to increase the shelf life surfactants or emulsifiers are added to it. Emulsifiers or surfactants tend to emulsify and remove the natural lipid when applied on the skin topically. Consequently, surfactant-free emulsions has been developed by the pharmaceutical company alternatives to conventional formulations with the help of stabilizers, for example, polymeric emulsifiers, with the end goal to yield adequately stable items with a cosmetically lovely appearance [17]

\section{Aerosol Foams:}

The aerosol foams is one of the well known kind of topical plan for treating different skin conditions including skin break out vulgaris. Aerosol foams have same physiochemical properties of other conventional carriers like gels, creams, lotions. The vehicle base of aerosol is having semisolid or liquid consistency. It also acts as moisturizing agents with better drying effects, high bioavailability of therapeutic agent. The aerosol base is dispensed through a gaspressurized that can easily discharge the foam through it. The product features like thickness, viscosity, texture, bubble size, density, stabile nature, and spread ability are determined by the type of formulation. The foams are easier to apply and can be applied over large hairy surfaces such as chest or back. [22] Sodium sulfacetamide 10\%-sulfur 5\% emollient vaporized froth was set up for the treatment of skin break out. An emollient froth of sodium sulfacetamide $10 \%$ showed for the topical treatment of skin break out vulgaris, rosacea, and seborrhea dermatitis has moved toward becoming available.[17]Spray formulation of antiacne agent Adapalene was prepared which could be able to develop a transparent thin film at the site of application. Evaluation included by determining the pressure test, drug content, minimum fill, leakage, delivery rate, delivery amount test, flammability, spray patterns, particles size, thickness of formed film and diffusion release profile etc. Eudragit (0.5\%) and Isopropyl alcohol (1.5\%) shows the highest release profile. Formulation with eudragit E100 (0.5\%). Stability studies shows that the optimized formulation were stable as per $\mathrm{ICH}$ guidelines at $40^{\circ} \mathrm{C} \pm 2{ }^{\circ} \mathrm{C}$ temperature.[23]

\section{Microsponges:}

Microsponges are made of synthetic polymers which are biologically inert particles and they have the ability to store a volume of a functioning specialist up to their very own weight. Moreover, inert constituents play a role in protection of active compounds from physical and 
natural debasement. The innovation of microsponge be capable of be utilized in assortment of detailing yet it is all the more especially utilized and fabricated as gels. It slowly release active agents when applied on the skin[24]. Microsponges of Benzoyl peroxide were prepared using ethyl cellulose resulted in the increment in the proportion of medication polymer and that were credited to a diminished inner porosity of the microsponges[17]. It was prepared with utilizing an emulsion dissolvable dispersion strategy and were evaluated through Medication content, molecule estimate examination and stacking yield were resolved in the readied microparticles. Microsponges shows they were circular fit as a fiddle and contained pores.[25]

\section{Fullerenes:}

These are particles made altogether out of carbon that take after an empty circle. In contact with the skin fullerenes relocate intracellularly through the skin. Along these lines, a fullerene could be utilized to 'trap' dynamic mixes and afterward discharge them into the epidermis once they are connected on the skin. In addition, fullerenes, themselves, are believed to be possibly powerful cancer prevention agents. Information are accounted for in the writing demonstrating that fullerenes are very much endured and they hold considerable guarantee in dermatologic and corrective applications. Polyhdroxylated fullerene (potent scavenging activity) was developed and evaluated the inhibitory impacts in-vitro on sebum creation in P. acne lipase activity in hamster sebocytes. The outcomes show that fullerene shows advantageous healthy skin regimen in treatment of inflammation vulgaris through decreasing sebum in the fiery reaction and by decreasing $P$. acnes lipase movement. [26]

\section{Penetration Enhancer Vesicles (PEVs):}

Penetration enhancer vesicles led to design, development for cutaneous delivery of minoxidil. The formulation consists of following penetration enhancers using phosphatidyl choline and different quantities of other penetration enhancers, 2-(2-ethoxyethoxy) ethanol (Transcutol), capryl-caproyl macrogol 8-glyceride and cineole mainly. It showed major enhancement of minoxidil testimony into the skin when contrasted and the exemplary readiness of liposomes and drug ethanolic solutions containing penetration enhancer. PEVs has also been used as a carrier delivery for minoxidil and diclofenac. These preparations include combination of liposome as a carrier and infiltration enhancer to expand the stratum corneum packing, and improvement of skin penetration and hence the delivery of the compounds.[27] Penetration enhancer vesicles (PEVs) were arranged by adding different hydrophilic penetration enhances like Labrasol® ,Transcutol ${ }^{\circledR}$ and propylene glycol Rheologic examination show that PEVs contain advanced than the liposomes. SEM study shows the indication that PEVs capacity to interrelate by means 
of the intercellular lipids leading to magnification of that area. It shows mainly improved cutaneous absorption of the drug accumulation into the skin and decreased transdermal delivery [28].

\section{Invasomes:}

Invasomes are the liposomal carriers containing little measures of ethanol and terpenes or terpene blends, which act as latent carriers with increased skin penetration. Invasomes results in better and higher skin penetration as compared to the liposomes and ethosomes. It results in improvement in drug's efficacy. Various lipophilic and hydrophilic enhancers like labrasol, transcutol, cineole have been used in the preparations to increase the skin penetration. Such penetration enhancer containing vesicles with terpenes as penetration enhancers were termed as invasome[29]

\section{EMERGING ROLE OF PENETRATION ENHANCERS FOR TOPICAL DELIVERY}

The human skin is a profound organ made out of numerous layers. Skin is most open organ in body. Its real capacities are; assurance of major or essential interior organs from the outside impacts, temperature directions, control of water yield and sensation. The skin of a normal grown-up body covers around surface territory of two square meters and gets around $33 \%$ of the blood coursing through the body. Skin is the unpredictable organ and permits the section of different synthetic concoctions into and over the skin. Skin fills in as the purpose of organization for fundamentally dynamic medications, the medication connected topically will be retained, first into the foundational dissemination and afterward transported to target tissues [44]. The epidermis, is the outermost layer or, in other words, and intense, made of various layers containing of two fundamental parts: the stratum corneum (SC) and the stratum germinativum; exterior coating constantly supersede through stratum germinativum. It provides waterproofing and serves as a barrier to infection. The dermis, sensitive in nature and thickest covering of skin or connective tissue mainly made up of blood vessels, sweat glands and different nerve endings. It serves as location for the appendages of skin. The subcutaneous greasy coating, made up of greasy covering and go about as a separator and station of calories[45]

\section{Role of Penetration Enhancer in Topical Delivery}

Penetration enhancer is used for the promotion of drug across the skin barriers. Number of mechanism is used for penetration of drug through the skin. To increase the penetration one of the way is interaction of polar head group of lipids with the penetration enhancers. The main reason is the lipid -lipid interaction which results in change in packaging of lipid and hence causes the facilitation of hydrophilic drugs. [46] The basic advantage of using penetration 
enhancers are: They are used for absorption of unabsorable drug through the skin barrier, mainly acts as a rate limiting factor also can enhance transdermal assimilation of topical arrangement in addition to entrance rate of drugs. However some disadvantages are also associated with these penetration enhancers that includes the viable fixation differs from medication to tranquilize and biochemical factors of enhancers may have some of the side effects in the body. [47]

\section{Perfect qualities of synthetic entrance enhancers.}

Preferably, infiltration enhancers reversibly diminish the obstruction of the stratum corneum exclusive of resulting in harming of suitable cells. A portion of the more attractive property for entrance enhancers are as follows and shown in Fig 5:

It thought to be non-harmful, non-disturbing and non-allergenic. Onset of activity ought to be fast, and term of action ought to be unsurprising and appropriate for the medication utilized and ought to include no pharmacological movement inside the body. i.e. ought not tie to receptor destinations. The entrance enhancers should work unidirectionally with the Endless supply of the enhancer, the horny layer ought to be promptly and completely recuperate its ordinary hindrance property. When removed from skin, obstruction properties should return both rapidly and fully. It ought to promptly figure into dermatological arrangements, transdermal gadgets, and skin glues [48] 


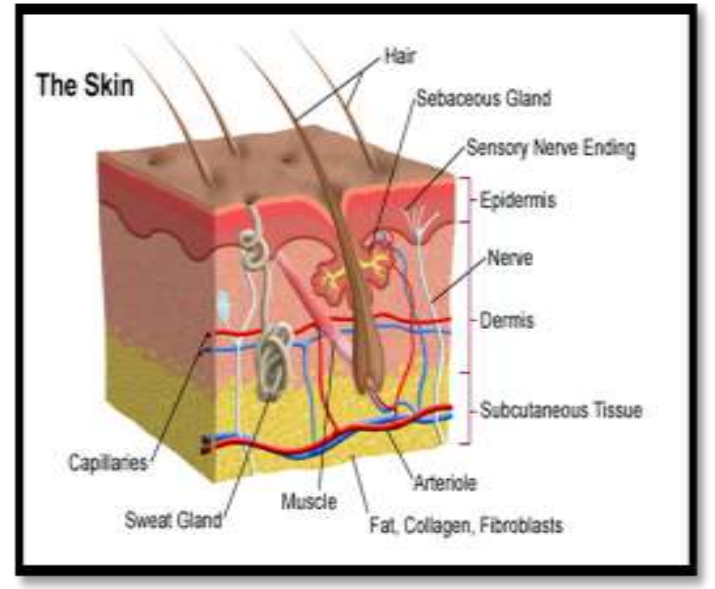

(a) Structure

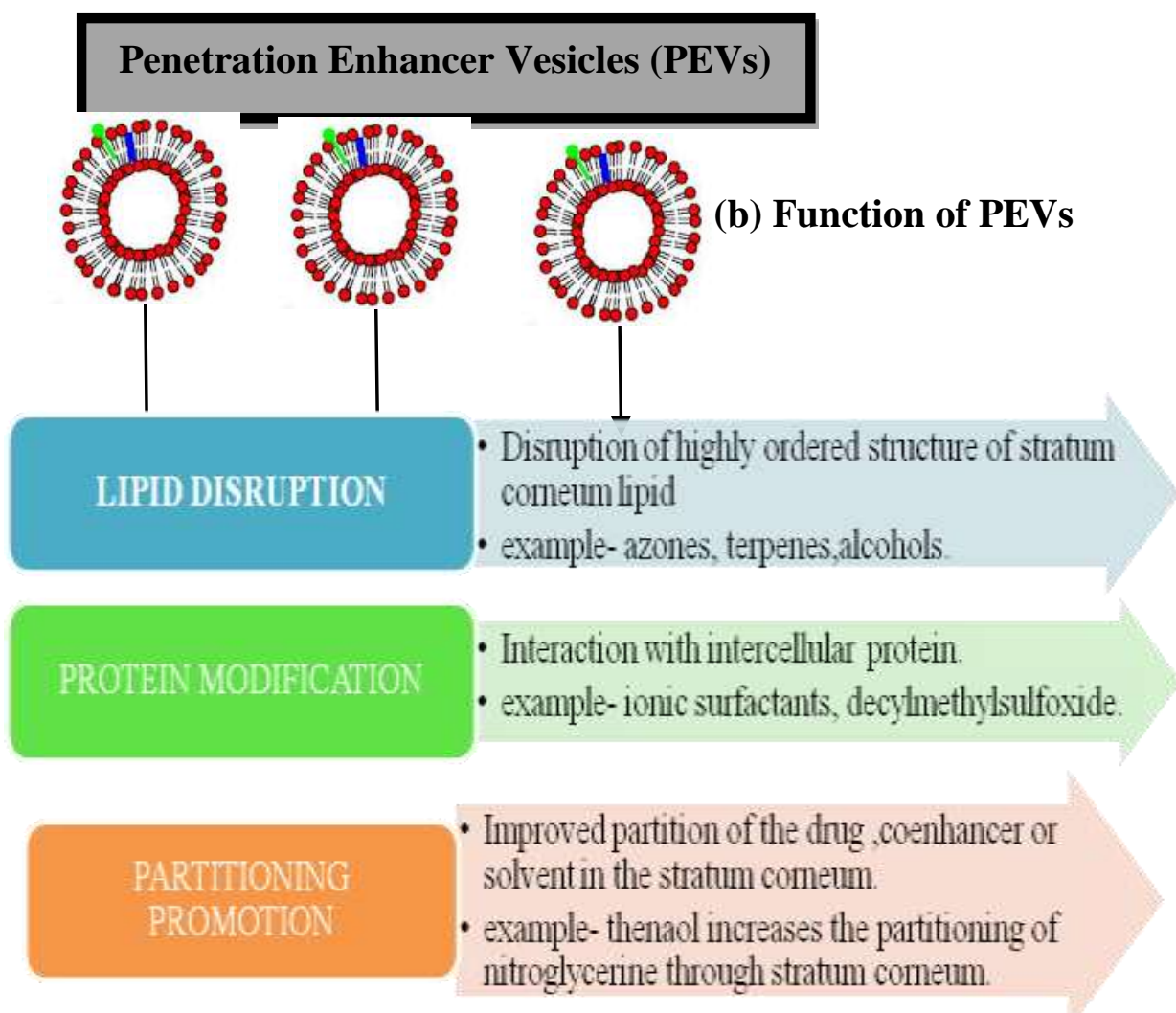

Figure 5: Schematic representation of (a) skin structure (b) function of PEVs

\section{Applications of Penetration Enhancer}

VESICLES (PEVs)FOR TOPICAL DELIVERY PEVs are one of the resourceful vesicular systems which can be prepared with the help of association of various PEVs to various phospholipids, in various sums. Among the different watery cosolvents, diethylene glycol monoethyl ether (Transcutol®), propylene glycol (PG), and glycerol were the most used in the preparations. Other PEVs with deliquescent, water miscible surfactants, for example, caprylocaproyl macrogol-8 glyceride, polyethylene glycol 400 (PEG 400), and 
decylpolyglucoside have also been used in various studies and preparations. Oleic acid was utilized to animate a negative surface charge and as a result it expanded the outright estimation of surface charge of the vesicles where as Cineole was tried and used as a lipotropic penetration enhancer into various formulations. However, the PEVs mainly obtained by the several techniques usually utilized in the planning of liposomal transporters. PEVs can be characterized with the help of various methods as to gain more knowledge about the properties of them and function of PE inside the membrane release of various medications. Transmission electron microscopy (TEM) and optical or enraptured light microscopy have been utilized for vesicle arrangement and anatomy, and vibrant and electrophoretic illumination diffusing. (Zetasizer nano-ZS) utilized for size dispersion and zeta potential assurance, elastic properties of the carrier prepared vesicles, also lipid bilayer properties make them ideal in respect to the rheological measurements [55].

\section{Evaluation Parameters for Acne}

Some evaluation parameters for acne includes microbial testing and endocrine testing. The microbial testing is usually employed for patients with acne where evaluation is for Gramnegative folliculitis. Gram negative folliculitis is characteristically diagnosed by means of culture of the lesions, and treatment is generally carried out with isotretinoin or an antibiotic which is lethal for bacteria. Another evaluating parameter is endocrine testing and the dominant role of androgens in acne pathogenesis is well recognized, endocrinologic examination is only justified in certain cases, as normal hormone levels are usually seen in patients having acne. Generally this examination parameters employed for patients having clinical features or a history of hyperandrogenism. In case of prepubertal children some symptoms include: acne, body odor, axillary or pubichair, augmented growth, enhanced bone density, and maturation of genital areas. The two screening tools which are used before specific testing of hormones are namely Growth charts and a hand film for bone age. Mostly the elevated level of androgens of ovarian origin is result of polycystic ovarian syndrome(PCOS).The diagnosis of PCOS is done on basis of hyperandrogenismin the existence of persistent oligomenorrhea in case of females of adolescent age group[11].

\section{FUTURE PROSPECTS}

Against maturing relics a input territory mainly of novel item improvement plus have been developing in significance quickly the same as buyers turn out to be increasingly mindful of how they are seen in and outside the working environment. Customers need to search useful for their age as far as might be feasible which can be seen by the up and coming pattern being used 
of against maturing items and requests. A modest bunch of advancements leads to a win in mainly liposomes and nano emulsions. Presently, because of expanded requests and mindfulness among buyers, more up to date advancements have raised. Prospect and new patterns incorporate utilization mainly by fullerenes, Nanoparticles nanocrystals, microsponges, invasomes by restorative items particularly for the treatment of skin[57]. 
Table 1: TREATMENT STRATEGIES OF ACNE

\begin{tabular}{|c|c|c|c|c|}
\hline Drug & \begin{tabular}{|l|} 
Marketed \\
Formulations
\end{tabular} & Brand Name & Dose & Adverse Effects \\
\hline \multicolumn{5}{|c|}{ TOPICAL TREATMENT OF ACNE } \\
\hline \multicolumn{5}{|c|}{ Topical Retinoids } \\
\hline Adapalene & $\begin{array}{l}\text { Cream }(0.1 \%) \\
\text { Gel }(0.1 \%, 0.3 \%)\end{array}$ & \begin{tabular}{|l|} 
Epilene-C, \\
Differin gel,
\end{tabular} & Once daily & $\begin{array}{l}\text { Dryness, erythema, photosensitivity, } \\
\text { pruritus, scaling, stinging }\end{array}$ \\
\hline Tazarotene & $\begin{array}{l}\text { Cream }(0.05 \%, 0.1 \%) \\
\text { Foam }(0.1 \%) \\
\text { Gel }(0.05 \%, 0.1 \%)\end{array}$ & $\begin{array}{l}\text { Tazorac cream, } \\
\text { Fabior foam, } \\
\text { Tazorac gel } \\
\end{array}$ & $\begin{array}{l}\text { Once daily in the } \\
\text { evening }\end{array}$ & \multirow[t]{2}{*}{$\begin{array}{l}\text { Dryness, erythema, photosensitivity, } \\
\text { pruritus. }\end{array}$} \\
\hline Tretinoin & $\begin{array}{l}\text { Cream }(0.025 \%, 0.05 \% \text {, } \\
0.1 \%) \\
\text { Gel }(0.01 \%, 0.025 \%)\end{array}$ & $\begin{array}{l}\text { Renova cream, } \\
\text { Retin-A gel, }\end{array}$ & $\begin{array}{l}\text { Once daily in the } \\
\text { evening }\end{array}$ & \\
\hline \multicolumn{5}{|c|}{ Topical Antibiotics } \\
\hline Erythromycin & \begin{tabular}{|l} 
Gel $(1 \%)$ \\
Lotion $(1 \%)$
\end{tabular} & $\begin{array}{l}\text { Erygel } \\
\text { Akne-mycin }\end{array}$ & $\begin{array}{l}\text { Twice daily (gel: } \\
\text { once or twice daily) }\end{array}$ & \multirow[t]{2}{*}{$\begin{array}{l}\text { Burning, dryness, erythema, oiliness, } \\
\text { pruritus }\end{array}$} \\
\hline Clindamycin & $\begin{array}{l}\text { Gel }(1 \%) \\
\text { Lotion }(1 \%) \\
\end{array}$ & Clinda gel & Twice daily & \\
\hline \multicolumn{5}{|c|}{ Topical Combinations } \\
\hline Adapalene/Bpo & $\begin{array}{l}\text { Foam }(1 \%) \\
\text { Gel }(1 \%) \\
\text { Lotion }(1 \%)\end{array}$ & Epiduo Gel & $\begin{array}{l}\text { Twice daily (gel: } \\
\text { once or twice daily) }\end{array}$ & \multirow[t]{3}{*}{$\begin{array}{l}\text { Burning, dryness, erythema, oiliness, } \\
\text { pruritus }\end{array}$} \\
\hline Clindamycin/Bpo & $\begin{array}{l}\mathrm{Gel}(1.2 \% / 2.5 \% \\
1.2 \% / 5 \%)\end{array}$ & Benzaclin gel & $\begin{array}{l}\text { Once daily in the } \\
\text { evening }\end{array}$ & \\
\hline Clindamycin/Tretinoin & Gel $(1.2 \% / 0.025 \%)$ & Veltin gel & Once daily & \\
\hline \multicolumn{5}{|c|}{ SYSTEMIC TREATMENT OF ACNE } \\
\hline \multicolumn{5}{|c|}{ Oral Antibiotic- Tetracycline } \\
\hline $\begin{array}{l}\text { Tetracycline } \\
\text { Oxy-tetracycline }\end{array}$ & Capsule 250mg,500mg & Sumycin & 200-500mg daily & GI upset, tooth staining \\
\hline Doxycycline & $\begin{array}{l}\text { Capsule }(50-150 \mathrm{mg}) \\
\text { Tablet }(50-150 \mathrm{mg})\end{array}$ & Acticlate tablet & 50-100 mg daily & Gastrointestinal upset, photosensitivity \\
\hline minocycline & Tablet ( 45-135 mg) & Minocin & 50-100 mg daily & Vertigo, hyperpigmentation of skin and \\
\hline
\end{tabular}




\begin{tabular}{|l|l|l|l|l|}
\hline & & & & oral mucosa \\
\hline Macrolides- Erythromycin & Gel (2\%) & Emgel & Applied daily & $\begin{array}{l}\text { Gastrointestinal upset, vaginal candidiasis, } \\
\text { emergence of resistance of P. acnes }\end{array}$ \\
\hline clindamycin & $\begin{array}{l}\text { Foam }(1 \%) \\
\text { Gel }(1 \%) \\
\text { Lotion (1\%) }\end{array}$ & $\begin{array}{l}\text { Clindamax gel, } \\
\text { Cleocin-T } \\
\text { pruritus }\end{array}$ & $\begin{array}{l}\text { 250mg twice times } \\
\text { a day }\end{array}$ & $\begin{array}{l}\text { Burning, dryness, erythema, oiliness, } \\
\text { HORMONAL TREATMENT FOR ACNE }\end{array}$ \\
\hline Spirnolactone & $\begin{array}{l}\text { Tablet }(25 \mathrm{mg}, 50 \mathrm{mg}, \\
100 \mathrm{mg})\end{array}$ & Aldactone & 25-100mg daily & $\begin{array}{l}\text { Menstrual irregularities, contraindicated in } \\
\text { pregnancy }\end{array}$ \\
\hline Prednisone & variable & Prelone & $2.5-5 \mathrm{mg}$ daily & Adrenal suppression \\
\hline $\begin{array}{l}\text { Dexamethasone } \\
\text { variable }\end{array}$ & $\begin{array}{l}\text { Dexamethasone } \\
\text { Intenso }\end{array}$ & $0.125-0.5 \mathrm{mg}$ daily & Adrenal suppression \\
\hline $\begin{array}{l}\text { Cyproterone acetate/ethinyl } \\
\text { estradiol }\end{array}$ & variable & Diane-35 & $2 \mathrm{mg} / 35-50 \mu \mathrm{g}$ & $\begin{array}{l}\text { Vascular thrombosis, melasma, weight } \\
\text { gain }\end{array}$ \\
\hline Levonorgestrel/ethinyl & variable & Levora & $\begin{array}{l}\text { Vascular thrombosis, melasma, weight } \\
\text { gain }\end{array}$ \\
\hline
\end{tabular}

Table 2: Different Vesicles as a Carrier for Topical Delivery

\begin{tabular}{|c|c|c|c|c|c|}
\hline Nano carrier Type & Aim of The Study & Drug & Composition & Study Findings & Ref. \\
\hline \multirow[t]{3}{*}{ Liposomes } & $\begin{array}{l}\text { To improve the } \\
\text { antibacterial efficacy of } \\
\text { benzoyl peroxide }\end{array}$ & $\begin{array}{l}\text { Benzoyl } \\
\text { peroxide }\end{array}$ & Phosphatidylcholine, cholestrol & $\begin{array}{l}\text { Significant antibacterial effect in the } \\
\text { infundibula against both P. acne \& } \\
\text { Micrococcaceae was observed as compared } \\
\text { to the conventional formulation }\end{array}$ & {$[29]$} \\
\hline & $\begin{array}{l}\text { To improve the stability } \\
\text { and the thermodynamic } \\
\text { activity }\end{array}$ & tretinoin & $\begin{array}{l}\text { Soy phosphatidylcholine, } \\
\text { Cholesterol, dicetylphosphate } \\
\text { (DCP), Stearylamine }\end{array}$ & $\begin{array}{l}\text { Increased stability \& drug retention were } \\
\text { achieved. }\end{array}$ & {$[30]$} \\
\hline & $\begin{array}{l}\text { To increase skin } \\
\text { targeting and skin } \\
\text { deposition and reduce } \\
\text { skin irritation }\end{array}$ & isotretnoin & $\begin{array}{l}\text { soya phosphatidylcholine, , 6- } \\
\text { carboxyfluorescein, Span 60, } \\
\text { span } 80, \text { and cholesterol, HP } \\
\beta \text { Cyclodextrin }\end{array}$ & $\begin{array}{l}\text { Increase skin targeting, drug deposition and } \\
\text { decrease skin irritation were observed }\end{array}$ & {$[31]$} \\
\hline Niosome & $\begin{array}{l}\text { To improves skin } \\
\text { retention, }\end{array}$ & erythromycin & Span, tweens, cholesterol. & $\begin{array}{l}\text { Niosomal gel was significantly more stable } \\
\text { as compared to plain drug gel and marketed }\end{array}$ & {$[32]$} \\
\hline
\end{tabular}




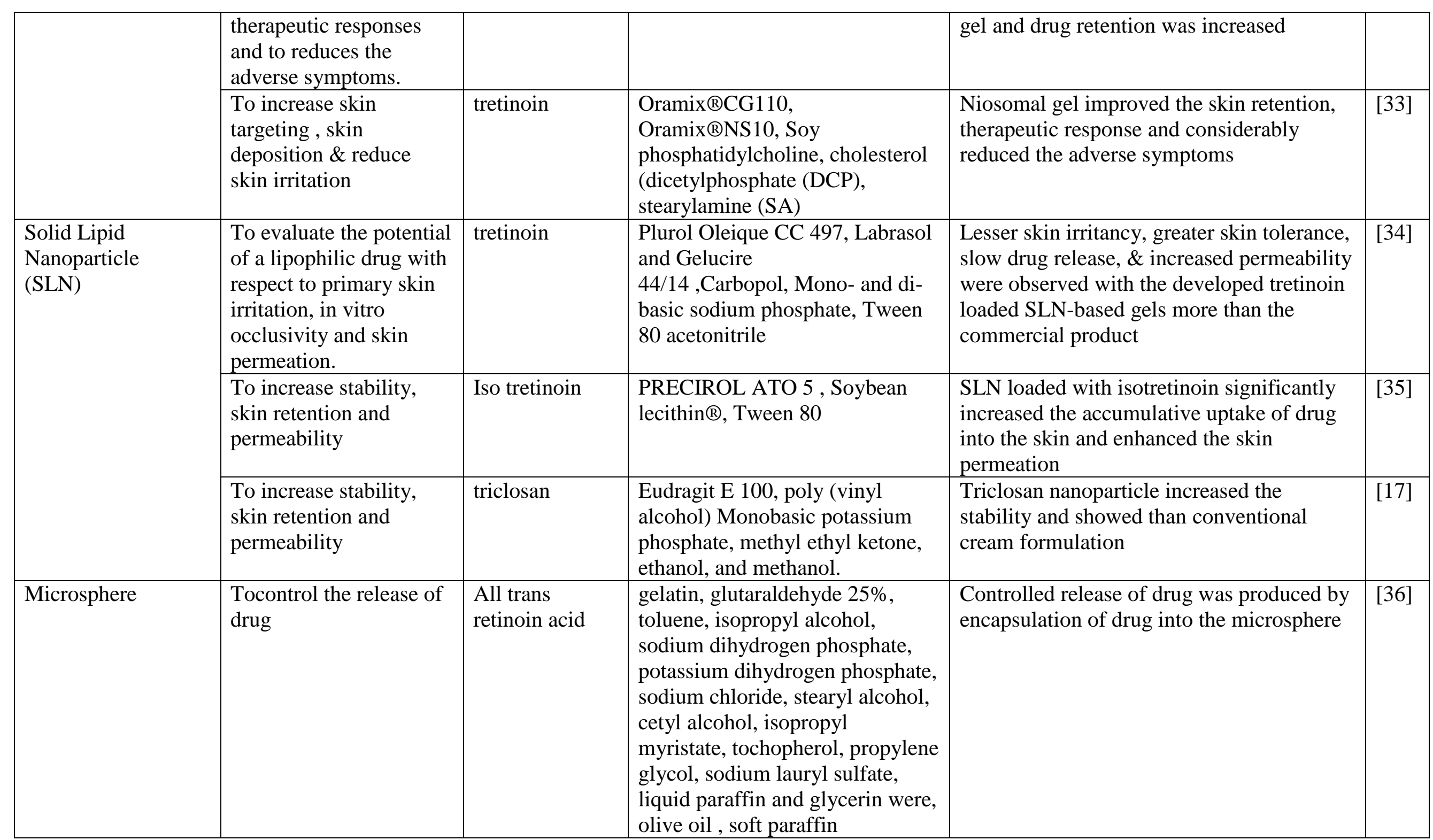




\begin{tabular}{|c|c|c|c|c|c|}
\hline & $\begin{array}{l}\text { To reduce skin irritation } \\
\text { on topical treatment. }\end{array}$ & $\begin{array}{l}\text { Benzoyl } \\
\text { peroxide }\end{array}$ & Benzoyl peroxide cream & $\begin{array}{l}\text { Cream containing microspheres of benzoyl } \\
\text { peroxide offered favorable efficacy with a } \\
\text { very low potential for irritation }\end{array}$ & {$[37]$} \\
\hline \multirow[t]{2}{*}{ Hydrogel } & $\begin{array}{l}\text { To increase the } \\
\text { permeability through } \\
\text { skin. }\end{array}$ & triclosan & $\begin{array}{l}\text { Transcutol CG,SPA and } \\
\text { dihydroxy aluminum } \\
\text { aminoacetate ,Polyacrylic acid } \\
\text { L(p)-Tartaric acid, Glycerin, } \\
\text { Carboxymethylcellulose }\end{array}$ & $\begin{array}{l}\text { To increase release permeation and reduce } \\
\text { skin irritation of tretinoin. }\end{array}$ & [38] \\
\hline & $\begin{array}{l}\text { To increase release } \\
\text { permeation and reduce } \\
\text { skin irritation of } \\
\text { tretinoin. }\end{array}$ & tretinoin & $\begin{array}{l}\text { dimethyl- } \beta \text {-cyclodextrin } \\
\text { Hydroxypropylmethylcellulose, } \\
\text { glycerine and potassium sorbate }\end{array}$ & $\begin{array}{l}\text { The complexation of tretinoin with } \\
\text { dimethyl- } \beta \text {-cyclodextrin overcome the } \\
\text { drug's low water solubility thereby } \\
\text { increasing drug release and enhanced the } \\
\text { drug permeation by promoting skin } \\
\text { absorption and alleviate drug inducing local } \\
\text { irritation }\end{array}$ & [39] \\
\hline \multirow[t]{2}{*}{ Microemulsion } & $\begin{array}{l}\text { To increase skin } \\
\text { permeation and skin } \\
\text { retention }\end{array}$ & tretinoin & $\begin{array}{l}\text { Isopropyl myristate, Tween } 80 \\
\text { and span } 80 \text { Lecithin ,n-Octanol } \\
\text { and dehydrated ethanol. }\end{array}$ & $\begin{array}{l}\text { Novel microemulsion increases tretinoin } \\
\text { penetration through skin and maximum } \\
\text { amount of drug retained as compare to plain } \\
\text { drug in solution, gel and marketed } \\
\text { preparation }\end{array}$ & $\begin{array}{l}20, \\
40]\end{array}$ \\
\hline & $\begin{array}{l}\text { To increase lipophilicity } \\
\text { and skin permeability }\end{array}$ & Retinoic acid & $\begin{array}{l}\text { phenylalanine methyl ester, } \\
\text { hydrochloride ,phenylalanine } \\
\text { ethyl ester, hydrochloride } \\
\text {,histidine methy ester, } \\
\text { dihydrochloride ,tryptophan } \\
\text { methyl ester, hydrochloride and } \\
\text { valine methyl ester hydro } \\
\text { chloride, Soya lecithin, Caprylyl- } \\
\text { caplyl gluco side, Isopropyl } \\
\text { myristate (IPM), 1,2 hexanediol } \\
\end{array}$ & $\begin{array}{l}\text { The } \mathrm{O} / \mathrm{W} \text { micro emulsions containing a } \\
\text { counter ion increased the skin permeability } \\
\text { and lipophilicity of drug. }\end{array}$ & {$[41]$} \\
\hline Microsponge & To reduce skin irritation & $\begin{array}{l}\text { Benzoyl } \\
\text { peroxide }\end{array}$ & $\begin{array}{l}\text { poly vinyl alcohol, } \\
\text { dichloromethane, acetone, } \\
\text { methanol, benzophenone, liquid }\end{array}$ & $\begin{array}{l}\text { Controlled release and reduced skin } \\
\text { irritation }\end{array}$ & {$[24]$} \\
\hline
\end{tabular}




\begin{tabular}{|l|l|l|l|l|}
\hline & & & $\begin{array}{l}\text { paraffin, triethanolamine, stearic } \\
\text { acid }\end{array}$ & \\
\cline { 2 - 5 } & $\begin{array}{l}\text { To reduce cutaneous } \\
\text { side effect }\end{array}$ & Tretinoin & $\begin{array}{l}\text { active ingredients, which are } \\
\text { immiscible with water surfactants } \\
\text { and dispersant }\end{array}$ & $\begin{array}{l}\text { Controlled release of tretinoin with reduced } \\
\text { cutaneous side effects }\end{array}$ \\
\hline Aerosol & $\begin{array}{l}\text { To reduce the volatility } \\
\text { and maintain } \\
\text { antibacterial activity }\end{array}$ & Juniper oil & $\begin{array}{l}\text { Glycerol behenate and glycerol } \\
\text { palmitostearate juniper oil, } \\
\text { Hexane polyoxyethylene-sorbitan } \\
\text { monooleate }\end{array}$ & $\begin{array}{l}\text { Juniper oil solid lipid microparticles } \\
\text { substantially maintain the oil loaded inside } \\
\text { their lipidic structure, reducing its volatility } \\
\text { and retaining its antibacterial activity. }\end{array}$ \\
\hline $\begin{array}{l}\text { Penetration } \\
\text { Enhancer } \\
\text { Containing Vesicles }\end{array}$ & $\begin{array}{l}\text { To enhance the delivery } \\
\text { of tretinoin into the skin. }\end{array}$ & tretinoin & $\begin{array}{l}\text { Soy phosphatidylcholine, } \\
\text { Decylpolyglucoside, ethanol, } \\
\text { caprylocaproyl } \\
\text { macrogol 8-glyceride, Propylene } \\
\text { glycol }\end{array}$ & $\begin{array}{l}\text { Improved cutaneous retention. Evidence of } \\
\text { PEVs' interaction with intercellular lipid }\end{array}$ \\
\hline
\end{tabular}

\section{Table 3: Different Penetration Enhancers \& their composition and indication as PEVs}

\begin{tabular}{|c|c|c|c|c|c|}
\hline S.no & $\begin{array}{l}\text { Types of } \\
\text { penetration } \\
\text { enhancers }\end{array}$ & Mechanism of action & Examples & Applications & Ref \\
\hline 1. & Physical enhancers & $\begin{array}{l}\text { Rate control over the } \\
\text { release and transdermal } \\
\text { permeation of drugs }\end{array}$ & $\begin{array}{l}\text { 1.sonophoresis 2.electroporation } \\
\text { 3.iontophoresis } 4 \text {.Radiofrequency } \\
\text { 5.thermophoresis } \\
\text { 6.Needless injection } \\
\text { 7.magnetophoresis } \\
\text { 8.phonophoresis } \\
\text { 9.hydration of SC } \\
\text { 10.stripping of SC } \\
\text { 11.skin abration and stretching }\end{array}$ & $\begin{array}{l}\text { 1. Application of microneedles- } \\
\text { Insulin delivery, Cutaneous fluid } \\
\text { extraction and glucose monitoring. } \\
\text { 2. magnetophoresis- In vitro } \\
\text { studies showed a magnetically } \\
\text { induced enhancement in benzoic } \\
\text { acid flux, which was observed to } \\
\text { increase with the strength of the } \\
\text { applied magnetic field. }\end{array}$ & {$[45]$} \\
\hline 2. & Drug vehicle based & $\begin{array}{l}\text { Oppositely charged } \\
\text { species to a charged } \\
\text { drug, formation of an ion } \\
\text { pair in which charges are } \\
\text { neutralized so drug }\end{array}$ & $\begin{array}{l}\text { 1.Prodrugs \& Ion pairs } \\
\text { 2. Chemical potential of drug } \\
\text { 3. Eutectic systems } \\
\text { 4. Complexes }\end{array}$ & $\begin{array}{l}\text { 1. The poor permeability of the } \\
\text { polar 6- mercaptopurine was } \\
\text { increased up to } 240 \text { times using S- } \\
\text { 6- acyloxymethyl and 9- } \\
\text { dialkylaminomethyl promoieties. }\end{array}$ & [49] \\
\hline
\end{tabular}




\begin{tabular}{|c|c|c|c|c|c|}
\hline & & $\begin{array}{l}\text { permeate through the } \\
\text { stratum corneum }\end{array}$ & & $\begin{array}{l}\text { 2. Derivatives of - cyclodextrin } \\
\text { with increased water solubility are } \\
\text { most commonly used in } \\
\text { pharmaceutical formulation. }\end{array}$ & \\
\hline 3. & Chemical enhancers & $\begin{array}{l}\text { These include three } \\
\text { mechanism } \\
\text { 1. By disturbing the } \\
\text { ordered structure of } \\
\text { Stratum corneum. } \\
\text { 2. By interacting with } \\
\text { the proteins } \\
\text { (intercellular). } \\
\text { 3. by improving drug } \\
\text { partition through startum } \\
\text { corneum }\end{array}$ & $\begin{array}{l}\text { 1.Sulphoxides - } \\
\text { Dimethylsulphoxides(DMSO), } \\
\text { dimethylformamide(DMF), } \\
\text { dimethyl acetamide(DMAC) } \\
\text { 2. Alcohols } \\
\text { 3. Polyols } \\
\text { 4. Alkanes } \\
\text { 5. Fatty acids-Lauric acid, } \\
\text { Myristic acid, Capric acid } \\
\text { 6. Esters } \\
\text { 7. Amines and amides } \\
\text { 8. Terpenes } \\
\text { 9. Surface active agents-Sodium } \\
\text { lauryl sulphate(SLS), } \\
\text { Benzalkonium chloride }\end{array}$ & $\begin{array}{l}\text { 1. Ethanol increases the } \\
\text { permeation of ketoprofen from a } \\
\text { gel-spray formulation and } \\
\text { triethanolamine salicylate from a } \\
\text { hydrophilic emulsion base. } \\
\text { Propylene glycol promotes the } \\
\text { flux of heparin sodium and } \\
\text { verapamil hydrochloride. } \\
\text { 2. Pyrrolidones have been used as } \\
\text { permeation enhancers for various } \\
\text { molecules with hydrophilic (e.g. } \\
\text { 5-fluorouracil and } \\
\text { sulphaguanidine) and lipophilic } \\
\text { (betamethasone-17- benzoate and } \\
\text { progesterone) permeate }\end{array}$ & {$[50]$} \\
\hline 4. & $\begin{array}{l}\text { Natural penetration } \\
\text { enhancer }\end{array}$ & $\begin{array}{l}\text { Partitioncoefficient } \\
\text { Diffusion coefficient } \\
\text { Lipid Extraction } \\
\text { Drug Solubility } \\
\text { Molecular orientation of } \\
\text { terpenes molecule with } \\
\text { lipid bilayer }\end{array}$ & $\begin{array}{l}\text { Terpenes-Menthol, Linalool, } \\
\text { Limonene, Carvacrol. Essential } \\
\text { oil-Basil oil, Neem oil, } \\
\text { Eucalyptus, Chenopodium }\end{array}$ & $\begin{array}{l}\text { 1. Chenopodium, have been found } \\
\text { to be effective penetration } \\
\text { enhancers for } 5 \text {-flouorouracil } \\
\text { transversing human skin in vivo } \\
\text { 2.L-menthol has been used to } \\
\text { facilitate in vitro permeation of } \\
\text { morphine hydrochloride. }\end{array}$ & {$[51]$} \\
\hline \multicolumn{5}{|c|}{ COMPOSITION \& INDICATION OF PEVS } & \\
\hline S.No & Composition & Drug used & Indication & Invitro/ex vivo release study & Reference \\
\hline 1. & $\begin{array}{l}\text { Soy PC, } \\
\text { dicetylphosphate, } \\
\text { labrasol, Trc, cineole }\end{array}$ & minoxidil & $\begin{array}{l}\text { the most deformable PEVs } \\
\text { (labrasol and cineole) results in } \\
\text { high drug delivery dermally }\end{array}$ & $\begin{array}{l}\text { the highest drug accumulation was } \\
\text { found in the SC where PEV-1 } \\
\text { (labrasol) and PEV-3 (cineole) } \\
\text { enhanced minoxidil deposition by }\end{array}$ & {$[52]$} \\
\hline
\end{tabular}




\begin{tabular}{|c|c|c|c|c|c|}
\hline & & & & $\begin{array}{l}\text { a factor of about three in } \\
\text { comparison with the control ( } \mathrm{p}< \\
0.01) \text { while PEV-2 (transcutol) } \\
\text { slightly improved drug deposition } \\
\text { in comparison with the soy } \\
\text { lecithin liposomes (by a factor of } \\
1.3 ; \mathrm{p}<0.05) \text {. Therefore, the } \\
\text { tested PEVs showed to be a better } \\
\text { carrier for minoxidil than classic } \\
\text { liposomes }\end{array}$ & \\
\hline 2. & $\begin{array}{l}\text { Soy PC (P50), Trc, } \\
\text { decylpolyglucoside } \\
\text { (Or), labrasol, PG }\end{array}$ & tretinoin & $\begin{array}{l}\text { Improved cutaneous retention and } \\
\text { reduced transdermal delivery. }\end{array}$ & $\begin{array}{l}\text { ex vivo penetration and } \\
\text { permeation results have shown } \\
\text { that the presence of a hydrophilic } \\
\text { PE molecule in the formulation of } \\
\text { P50 liposomes is crucial for } \\
\text { improving dermal delivery of a } \\
\text { lipophilic drug such as tretinoin }\end{array}$ & [27] \\
\hline 3. & $\begin{array}{l}\text { Soy PC (P50), Trc, } \\
\text { labrasol, PG, PEG } \\
400\end{array}$ & Quercitin & $\begin{array}{l}\text { Drug skin accumulation is } \\
\text { affected with penetration } \\
\text { enhancer. }\end{array}$ & $\begin{array}{l}\text { It allowed the highest drug } \\
\text { accumulation into }(\sim 170 \mu \mathrm{g} / \mathrm{cm} 2) \\
\text { and through }(\sim 5 \mu \mathrm{g} / \mathrm{cm} 2) \text { the skin }\end{array}$ & {$[53]$} \\
\hline 4. & Soy PC (P50), Trc & Diclofenac sodium salt & $\begin{array}{l}\text { Synergic effect of Trc with PEVs' } \\
\text { bilayer results in fluidity and } \\
\text { perturbs intercellular lipids. }\end{array}$ & $\begin{array}{l}\text { results of the ex vivo (trans)dermal } \\
\text { drug delivery highlighted that } \\
\text { these formulations, especially } 10 \% \\
\text { TrcPEVs, are valuable candidates } \\
\text { for topical drug delivery of } \\
\text { NSAID diclofenac }\end{array}$ & [54] \\
\hline
\end{tabular}




\section{CONCLUSION}

The community is exceedingly values in wellbeing and excellence. Therefore antiageing definitions are ending up progressively well known. Number of organizations using nanomaterials offers antiageing items in the market which because of their extraordinary property of useful conveyance to the skin renders broadened adequacy. New innovations and methods are sneaking in the field of nanotechnology to enhance the corrective market much more, in spite of the fact that a considerable measure of research and human investigations in this field is required to get a genuine information.

\section{ACKNOWLEDGEMENTS}

The authors duly acknowledge to Delhi Pharmaceutical Sciences and Research University, for providing the support and facilities for writing of manuscript.

\section{REFERENCES}

1. White GM. Recent findings in the epidemiologic evidence, classification, and subtypes of acne vulgaris. Journal of the American Academy of Dermatology 1998;39:34-37.

2. Vos $\mathrm{T}$ et al. Years lived with disability (YLDs) for 1160 sequelae of 289 diseases and injuries 1990-2010: a systematic analysis for the global burden of disease study 2010;80:2163-2196.

3. Thiboutot $\mathrm{D}$ et al. New insights into the management of acne: an update from the Global Alliance to Improve Outcomes in Acne group. J. Am. Acad. Dermatol 2009;60:S1-S50.

4. Dreno B, Popli F. Epidemiology of acne. Dermatology 2003;206:7-10.

5. Ochsendorf F. Acne vulgaris Autoimmune skin diseases, proctology, environmental medicine 2009;4(1):36-51.

6. Hentsch B, Schwarz S. Use of valproic acid for the topical treatment of mild to moderate acne vulgaris. Google Patents. 2007.

7. Ray C, Trivedi P, Sharma V. Acne and its Treatment lines.International Journal of Research in Pharmaceutical and Biosciences 2013;3(1):1-16.

8. Vyas A, Sonker AK, Gidwani B. Carrier-Based Drug Delivery System for Treatment of Acne. The Scientific World Journal 2014;1-14.

9. Subotic M, Duran V. Treatment of acne vulgaris: a literature review. Serbian. Journal of Dermatology and Venereology 2010; 2(1):13-20.

10. Seth V, Mishra A. Acne vulgaris management: what's new and what's still true? International Journal of Advances in Medicine International Journal of Advances in 
medicine 2012 .

11. Zaenglein AL, Pathy AL, Schlosser BJ, Alikhan A, Baldwin HE, Berson DS, Bowe WP, Graber EM, Harper JC, Kang S, Keri JE. Guidelines of care for the management of acne vulgaris. Journal of the American Academy of Dermatology. 2016;74(5):945-73.

12. Garg T. Current nanotechnological approaches for an effective delivery of bio-active drug molecules in the treatment of acne. Artificial Cells, Nanomedicine, and Biotechnolog 2014; 1-8.

13. Wu X, Guy RH. Applications of nanoparticles in topical drug delivery and in cosmetics. Journal of Drug Delivery Science and Technology 2009;19(6):371-384.

14. Kumar V, Banga AK Intradermal and follicular delivery of adapalene Liposomes. Drug Dev Ind Pharm. Early Online 1-9.

15. Date AA, Naik B, Nagarsenkar MS. Novel Drug Delivery Systems: Potential in improving topical delivery of antiacne agents. Skin Pharmacology Physiology 2006;216.

16. Castro AG, Ferreira LAM. Novel vesicular and particulate drug delivery systems for topical treatment of acne. Expert Opinion, Drug Delivery 2008;5(6):665-679.

17. Liu J, Hu W, Chen H, Ni Q, Xu H, Yang X. Isotretinoin-loaded solid lipid nanoparticles with skin targeting for topical delivery. International Journal of Pharmaceutics 2017;328:191-195.

18. Domínguez-Delgado CL, Rodríguez-Cruz IM, Escobar-Chávez JJ, Calderón-Lojero IO, Quintanar-GuerreroD, GanemA. Preparation and characterization of triclosan nanoparticles intended to be used for the treatment of acne . European Journal of Pharmaceutics and Biopharmaceutics 2011;102 -107.

19. Shivane P, Sridevi G, Gopkumar P, Sujit P. Formulation and evaluation of sustain release microsphere of Tretinoin for the treatment of Acne vulgarise. Research Journal of Pharmacy and Technology 2013;6(10):1089-1093.

20. Jain AA, Garg NK, Jain A, Kesharwani P, Jain AK, Nirbhavne P, Tyagi RK. A synergistic approach of adapalene-loaded nanostructured lipid carriers, and vitamin $\mathrm{C}$ coadministration for treating acne. Drug Dev Ind Pharm.Early Online 2016;1-9.

21. Khanna S, Katare O P, Drabu S .Lecithin zed microemulsion for topical delivery of tretionoin. International Journal of Research in Drug Delivery 2010;2(4):711-719.

22. Sirvi K, Goyal P.K, Vyas B. Novel drug delivery system and its uses in the treatment of acne. International Journal of Pharmaceutical Erudition 2016;6(3):12-28. 
23. Pawar IP, Rajput RR, Vaghani SS, Katara BV .Formulation \& evaluation of topical spray of antiacne agent. Asian J Pharmaceutical Education \& Research 2015; (1):17-47.

24. Jotish M, Pranitha CN, Kundana P, Chandra Reddy GS. Novel drug delivery system and its use in the treatment of acne. International Journal of Pharmacy \& Technology 2010;2(1):41-53.

25. Jelvehgar M, Siahi-Shadbad MR, Azarm S, Martin GP, Nokhodchi A. The microsponge delivery system of benzoyl peroxide: preparation, characterization and release studies. International Journal of Pharmaceutics 2006;308(1-2):124- 132.

26. Inui S, Aoshim aH, Nishiyama A, Itami S. Improvement of acne vulgaris by topical fullerene application: unique impact on skin care. Nanomedicine: Nanotechnology, Biology, and Medicine 2011;7:238 - 241.

27. Gupta M, Agarwal U, Vyas SP. Nanocarrier-based topical drug delivery for the treatment of skin diseases . Expert Opinion, Drug Delivery 2012.

28. Manconi M, Sinicoa C, Caddeoa C, Vila AO, Valenti D, Fadda AM. Penetration enhancer containing vesicles as carriers for dermal delivery of tretinoin. International Journal of Pharmaceutics 2011;37-46.

29. Saudagar RB, BornareAS. Invasomes Novel Vesicular Carriers for Transdermal Drug Delivery. International Journal of Universal Pharmacy and Bio Sciences 2016;5(6).

30. Fluhr JW, Barsom O, Gehring W, Gloor M. Antibacterial efficacy of benzoyl peroxide in phospholipid liposomes. Dermatology 1999;198(3):273-277.

31. Sinicoa C, Manconia M, Peppi M, Laia F, Valentia D, Faddaa AM. Liposomes as carriers for dermal delivery of tretinoin: in vitro evaluation of drug permeation and vesicle skin interaction. Journal of Controlled Release 2005;103(1):123-136.

32. Kaur N, PuriR, Jain SK. Drug-cyclodextrin-vesicles dual carrier approach for skin targeting of anti-acne agent. American Association of Pharmaceutical Scientists 2010;11(2):528-537.

33. Jigar V, Vishal G, Tejas G, Vishal C, Umesh U. Formulation and characterization of topical gel of erythromycin entrapped into niosomes. International Journal of PharmTech Research 2011;3(3):1714-1718.

34. Manconi M, Sinico C, Valenti D, Lai F, Fadda AM. Niosomes as carriers for tretinoin: III. A study into the in vitro cutaneous delivery of vesicle-incorporated tretinoin. International Journal of Pharmaceutics 2006;311(1-2):11-19.

35. Mandawgade SD, PatravaleVB. Development of SLNs from natural lipids: application to topical delivery of tretinoin. International Journal of Pharmaceutics 2008;132-138. 
36. Liu G, Hu W, Chen H, Ni Q, Xu H, Yang X. Isotretinoin loaded solid lipid nanoparticles with skin targeting for topical delivery. International Journal of Pharmaceutics 2007;328(2):191-195.

37. Dinarvand R, Rahmania E, Farboda E. Gelatin microspheres for the controlled release of all-trans-retinoic acid topical formulation and drug delivery evaluation. Iranian Journal of Pharmaceutical Research 2003;2(1):47-50.

38. Bikowski J, Del RJ Q. Case reports: benzoyl peroxide microsphere cream as monotherapy and combination treatment of acne. Journal of Drugs in Dermatology 2008;7(6):590-595.

39. Lee TW, Kim JC, Hwang SJ. Hydrogel patches containing triclosan for acne treatment. European Journal of Pharmaceutics and Biopharmaceutics 2003;56(3):407-412.

40. Ascenso A, Vultos F, FerrinhoD, Salgado A, Filho SG, Ferrari V, Simoes S, Marques H.C.Effect of tretinoin inclusion in dimethyl-beta-cyclodextrins on release rate from a hydrogel formulation. Journal of Inclusion Phenomena and Macrocyclic Chemistry 2011;1-7.

41. Suthar ASM, Modi JD, Patel MP, Baria AH. Microemulsion-based gel formulation and evaluation of tretinoin for topical delivery. International Journal of Pharmaceutical Research 2009;1(4):28-34.

42. Trotta M, Ugazio E, Peira E, Pulitano C. Influence of ion pairing on topical delivery of retinoic acid from microemulsion. Journal of Controlled Release 2003;86(2-3):315-321.

43. D’Souza JL, More HN. The microsponge drug delivery system: for delivering an active ingredient by controlled time release. Pharma.info.net.6(3):62.

44. Gavini E, Sanna V, Sharma R, Juliano C, Usai M, Marchetti M, Karlsen J, Giunchedi P. Solid lipid microparticles (SLM) containing juniper oil as anti-acne topical carriers: preliminary studies. Pharmaceutical Development and Technology 2005;10(4):479-487.

45. Keleb E, Sharma RK, Mosa EB, Aljahwi AAZ. Transdermal drug delivery systemdesign and evaluation. International journal of advances in pharmaceutical sciences 2010;(1):201 -211.

46. Bavaskar K, Jain A, Patil M, Kalamkar R. The impact of penetration enhancers on transdermal drug delivery system: physical and chemical approach. International journal of pharma research \& review 2015;4(7).

47. Singla V, Saini S, Singh G, Rana AC, Joshi B. Penetration enhancers : a novel strategy for enhancing transdermal drug delivery. International Res J pharmacy 2011;2(12):32-36. 
48. Nikam S, Khatri N, Chavan M. Absorption promoter: an overview. Journal of biological and scientific operation 2016;4(1).

49. Pathan I.B, Setty CM. Chemical Penetration Enhancers for Transdermal Drug Delivery Systems. Tropical Journal of Pharmaceutical Research 2009;8(2):173-179.

50. Dhamecha D.L, Rathi AA, Saifee M, Lahoti SR, Dehghan HG. Drug vehicle based approaches of Penetration enhancement. Int J Pharm Pharma sciences 2009;1(1).

51. Jadhav JK, Sreenivas SA. Review on chemical permeation enhancer used in transdermal drug delivery system. International journal of science innovations and discoveries 2012; 2(6):204-217.

52. Mathur V, Satrawala Y, Rajput MS Physical and chemical penetration enhancers in transdermal drug delivery system. Asian Journal of Pharmaceutics. 2010.

53. Mura S, ManconiM, Sinico C, Valenti D, Fadda AM. Penetration enhancer-containing vesicles (PEVs) as carriers for cutaneous delivery of minoxidil. International Journal of Pharmaceutics 2009; 389:72-79.

54. Chessa M, Caddeo C, Valenti D, Manconi M, Sinico C, Fadda AM. Effect of Penetration Enhancer Containing Vesicles on the Percutaneous Delivery of Quercetin through New Born Pig Skin. Pharmaceutics 2011; (3):497-509.

55. Manconi M, Caddeo C, Sinico C, Valenti D, Mostallino MC, Lampis S, Monduzzi M, Fadda AM. Penetration enhancer-containing vesicles: Composition dependence of structural features and skin penetration ability. European J Pharma and Biopharmaceutics 2012;(82):352-359.

56. Sharma B, Sharma A. Future prospect of nanotechnology in development of anti-ageing formulations. International Journal of Pharmacy and Pharmaceutical Sciences 2012;4(3).

57. ManconiM, Sinico C, Fadda AM. Penetration Enhancer-Containing Vesicles for Cutaneous Drug Delivery. Springer-Verlag Berlin Heidelberg. 2016.

\section{AJPHR is}

Peer-reviewed

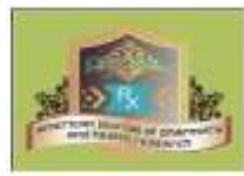

monthly

Rapid publication

Submit your next manuscript at editor@ajphr.com / editor.ajphr@gmail.com 